\title{
KARÁCSONKŐ VÁRA: EGY ELŐRETOLT HELYŐRSÉG A KÁRPÁTOK KELETI OLDALÁN
}

\section{Sófalvi András ${ }^{1}$}

Magyar Régészet 10. évf. (2021), 4. szám, pp. 27-38. https://doi.org/10.36245/mr.2021.4.3

Az , elöretolt helyörség” fogalmát aligha találjuk a középkori irott forrásokban, vagy középkorász történészekrégészek szakkifejezései között, viszont a Rejtö Jenötöl kölcsönzött cím nem pusztán hangzatos formula, hanem lényegi mondanivalót takar, mint látni fogjuk az alábbi irás tartalmából. A Keleti-Kárpátok moldvai oldalán, a Magyar Királyság kora újkorra, újkorra rögzült történelmi határain túl található karácsonkői vár környezetidegen középkori leletei, elsösorban fegyverek, félévszázaddal ezelötti felfedezésük óta sem kaptak elegendö figyelmet a magyar régészeti kutatásban. A vár kapcsolata a korabeli magyar várszervezettel, határvédelmi és politikai szerepének értékelése, valamint elpusztulása képezik vizsgálatom legfontosabb kérdéseit. ${ }^{2}$

Kulcsszavak: Karácsonkő, fa-földvár, várszervezet, határvédelem, Árpád-kor, fegyverek, brakteáta, tatárjárás

\section{VÁR A HEGYEKEN TÚL}

Karácsonkő vára jelentős vaskori előzményekkel rendelkező erődítmény, amely azonos a Ptolemaiosz által említett ókori Petrodavával. A 1960-as években itt végzett feltárások során olyan középkori leletegyüttes látott napvilágot, amelynek egyes darabjai párhuzam nélküliek voltak a korabeli moldvai leletanyagban és nyugati, hegyeken inneni kapcsolatokról tanúskodtak. A vár középkori tárgycsoportjairól átfogó publikáció jelent meg (SCORPAN, 1965), melyet később további leletek közzé tétele egészített ki (SPINEI, 1982). A kérdéssel mindeddig elsősorban román kutatók foglalkoztak, többé-kevésbé hangsúlyozva a leletcsoport egyedi jellegzetességeit, különféle értelmezési lehetőségeknek adva teret (kenézségi központ, erdélyi román részvétellel folytatott magyar keleti expanzió, kereskedelmi-politikai kapcsolatok stb.). A téma korántsem tekinthető lezártnak, sajnos további feltárások nem folytak a várban, így előrelépés elsősorban a tárgyi leletek összehasonlító vizsgálatától, és a lelőhely tágabb térbeli összefüggésbe helyezésétől és elemzésétől várható.

\section{A VÁR NÉVEREDETE, FÖLDRAJZI HELYZETE ÉS JELLEMZÖI}

A Keleti-Kárpátok kisebb tömbjeit képező Csalhótól és Tarkő-havastól keletre, az Aranyos-Beszterce folyó hegyek közül kinyíló völgytorkolatában épült karácsonkői vár (románul cetatea Bâtca Doamnei) a mai Piatra Neamț [tükörfordításban: Németkő] város közelében található (1. kép), több kilométer távolságban a Magyar Királyság történelmi határán túl. A helynév legkorábbi előfordulási formája 1395-ből (in terra nostra Molduana ante villam Karachonkw - ld. MÁLyusz, 1951, 3801) nem teszi kérdésessé, hogy az magyar eredetü. A településnek a középkorban jelentős magyar lakossága volt, akik számos helynevet hagytak maguk után, mint pl. a Kövesd-patak (románul Cuejd). (MikeCs, 1943, 459, 3. jz.)

A vár a Beszterce-völgyének déli oldalában, a folyó fölé kiugró hegyfokon (457 m), az oldalági Doamnei(Asszony)-patak torkolatától nyugatra magasodik (2-4. kép), stratégiai ponton. Az észak-dél irá-

Haáz Rezső Múzeum, Székelyudvarhely. E-mail: sofalvi@hotmail.com

2 Az itt közölt írás egy átfogó kutatás része, mely a karácsonkői várral és annak történelmi hátterével, kapcsolatrendszerével foglalkozik a Kárpátok mindkét oldalán. Ez a dolgozat elsősorban a leletek régészeti értékelését taglalja, eredményeim történelmi összefüggéseinek részletesebb kifejtésére egy nagyobb tanulmány keretében kerül sor. Kutatásaimat a Magyar Tudományos Akadémia Domus Hungarica Scientiarium et Artium ösztöndíjprogramjai támogatták (4/2021/HTMT, 1944/13/2021/HTMT). A tanulmány a Nemzeti Kutatási, Fejlesztési és Innovációs Hivatal által támogatott „A tatárjárás Magyarországon és a mongol hódítás eurázsiai összefüggései” címü kutatási programmal együttmüködésben készült (projekt azonosító: K 128880). 


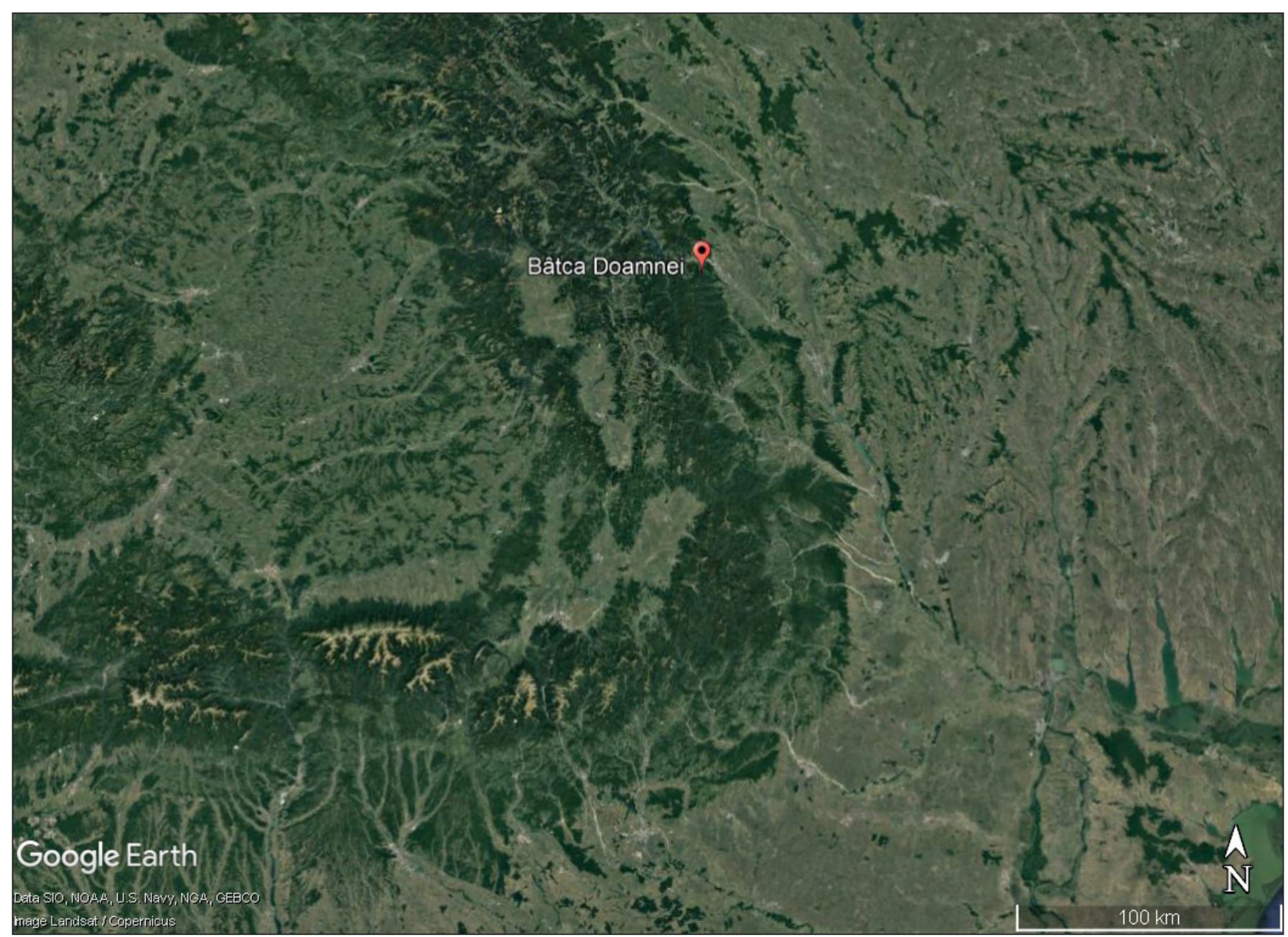

1. kép. Karácsonkö helyzete a Kárpátok térségében (forrás: Google Earth)

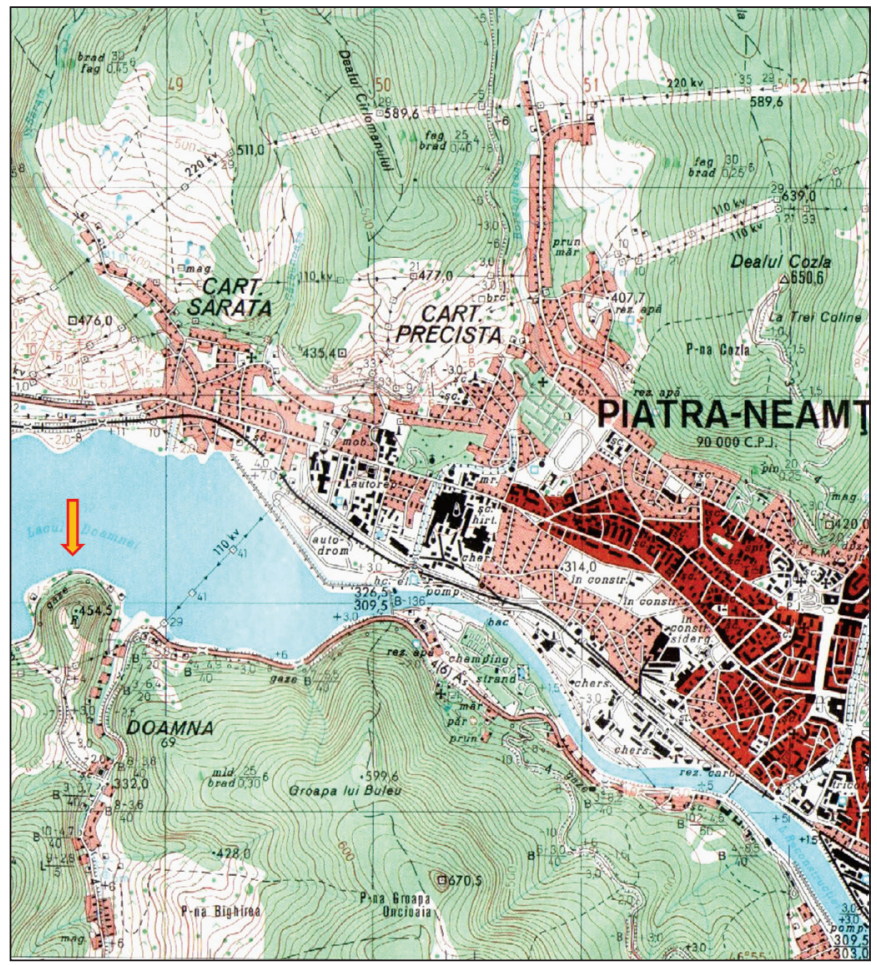

2. kép. Karácsonkö topográfiája az 1:5000 kataszteri térkép szerint

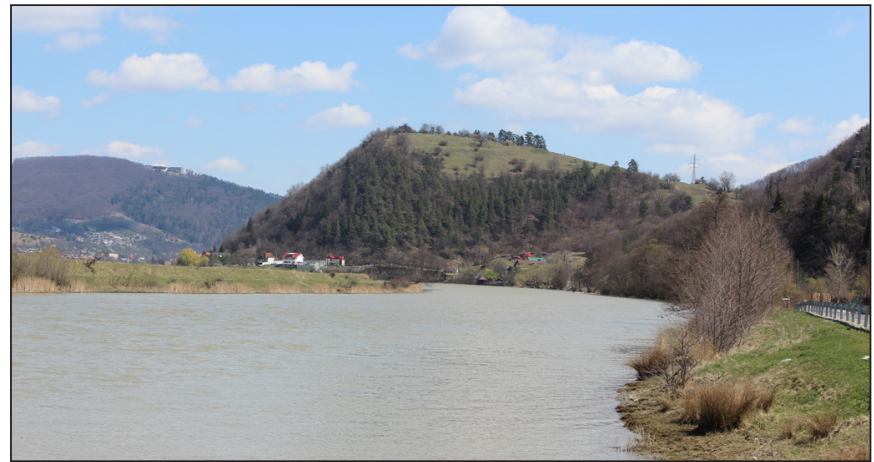

3. kép. A várhegy nyugatról (a szerzö felvétele)

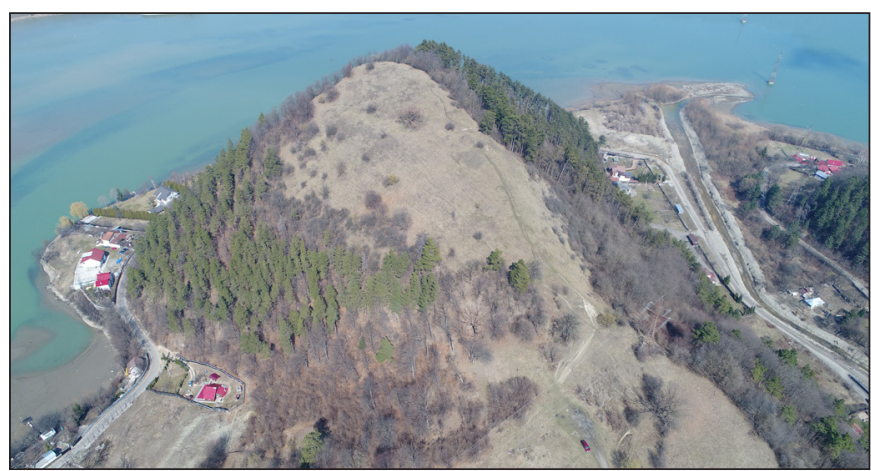

4. kép. A várhegy légi felvétele délröl (CloudScale Digital Kft.) 
Sófalvi András • Karácsonkö vára: egy elöretolt helyörség a Kárpátok keleti oldalán

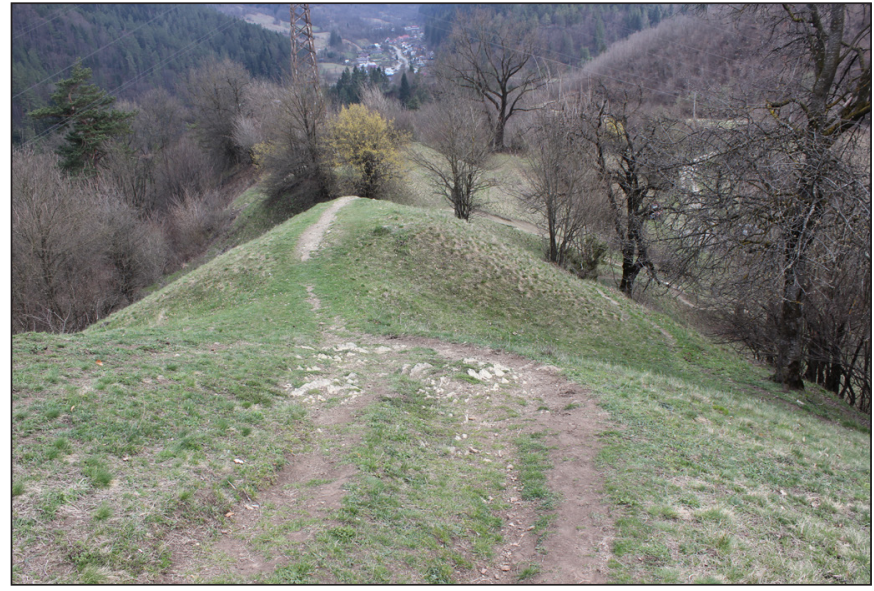

5. kép. A hegygerinc déli végét határoló földmüvek (a szerzö felvétele) nyú magaslatot délröl lehetett megközelíteni egy keskeny gerincen keresztül, melyet négy, sziklába mélyedő árokkal vágtak át (5. kép), ezek a régészeti kutatások szerint késő vaskoriak, ám középkori megújításuk/újra használatuk valószínü. Tölük 100150 m-re északra szabályos kőtömbökből agyagba rakott dák kori kőfal (opus quadratum) maradványait tárták fel, efölött pedig középkori paliszád leégett nyomait figyelték meg (6. kép). A vártető nyugati lejtőjén, a vaskori kőfallal erődített terasz szintjétől alacsonyabban húzódó mesterséges tereplépcső mentén szintén elpusztult faszerkezet jelezte a középkori erődítés létét (SCORPAN, 1965, 441442; Agrigoroarei, 2008, 11-12). Középkori lele-

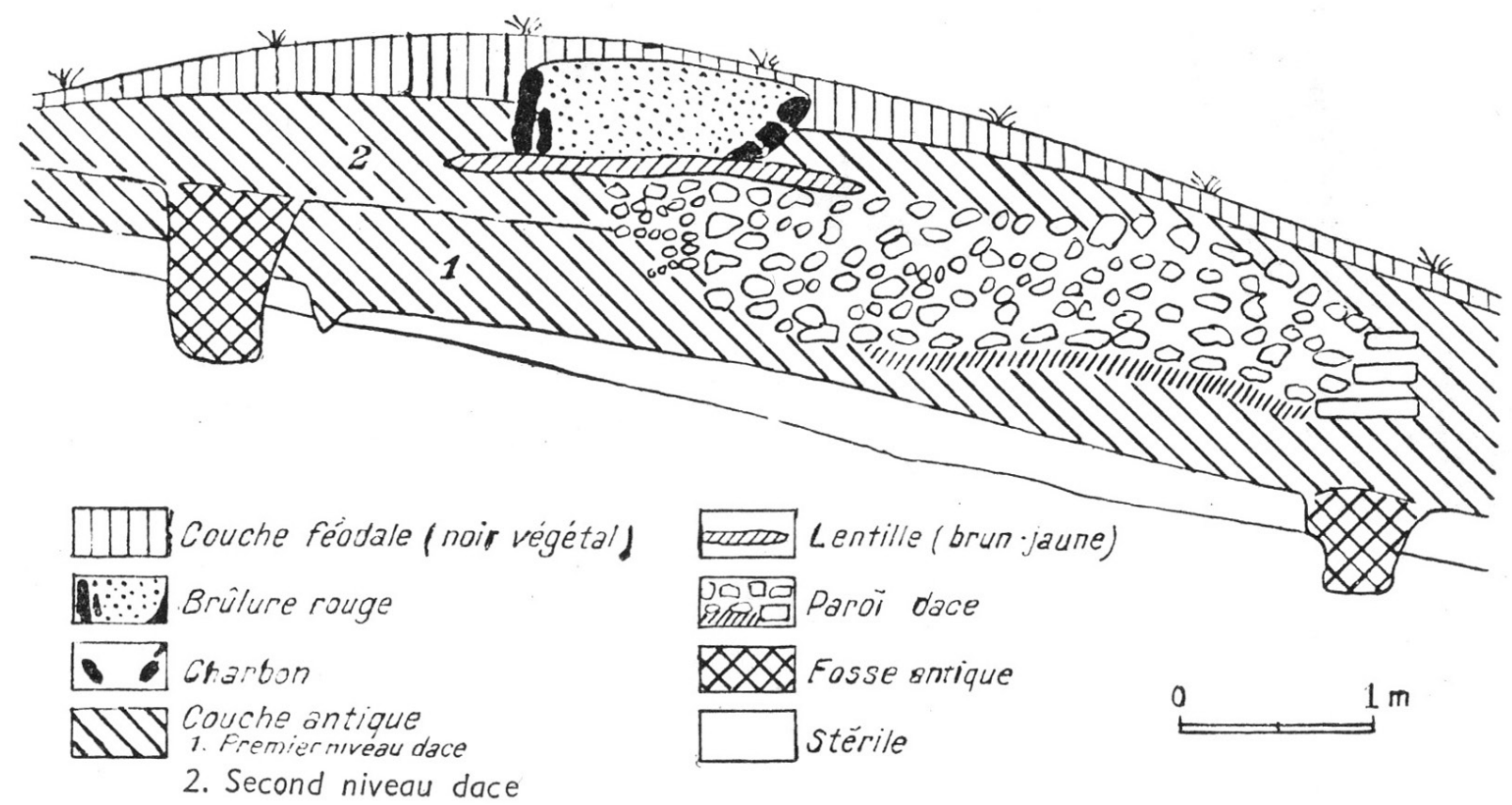

6. kép. Középkori paliszád nyomai a dák köfal fölött a déli oldalon (SCORPAN 1965, 443, Fig. 3)

tek szórványosan vagy csoportosan az erődítmény magaslatán és keleti peremén is kerültek napvilágra, itt a korabeli élettevékenység nyomait vékony földréteg (vastagsága max. $0,15 \mathrm{~m}$ ) jelezte a vastag antik kultúrréteg fölött, felszíni építményekre utaló jelenségekkel. A várhegy nyugati oldalán, a plató szintje alatt látható markáns teraszon (7. kép) két földbe ásott kemence, az 5. számmal jelölt kutatófelületen egy kunyhóként értelmezett objektum (ovális formájú, 2,10 m hosszú létesítmény), illetve két további kemence került napvilágra, környezetükben középkori leletekkel. 1962-ben három keletelt temetkezést tártak fel a várban, egyik csontváz gerincén a leírások szerint kardcsapás nyomai lát-

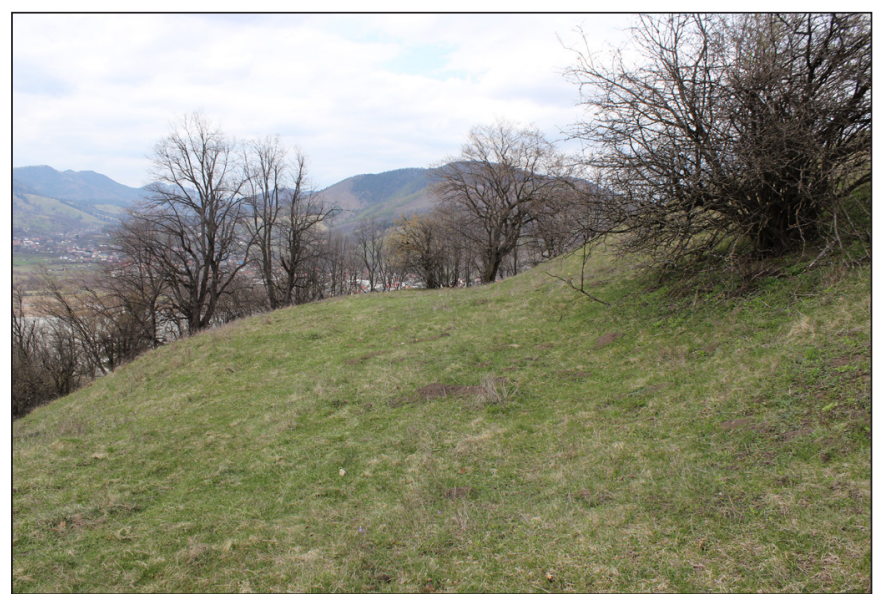

7. kép. A várhegy nyugati oldalán található mesterséges terasz délröl (a szerzö felvétele) 
Sófalvi András • Karácsonkö vára: egy elöretolt helyőrség a Kárpátok keleti oldalán

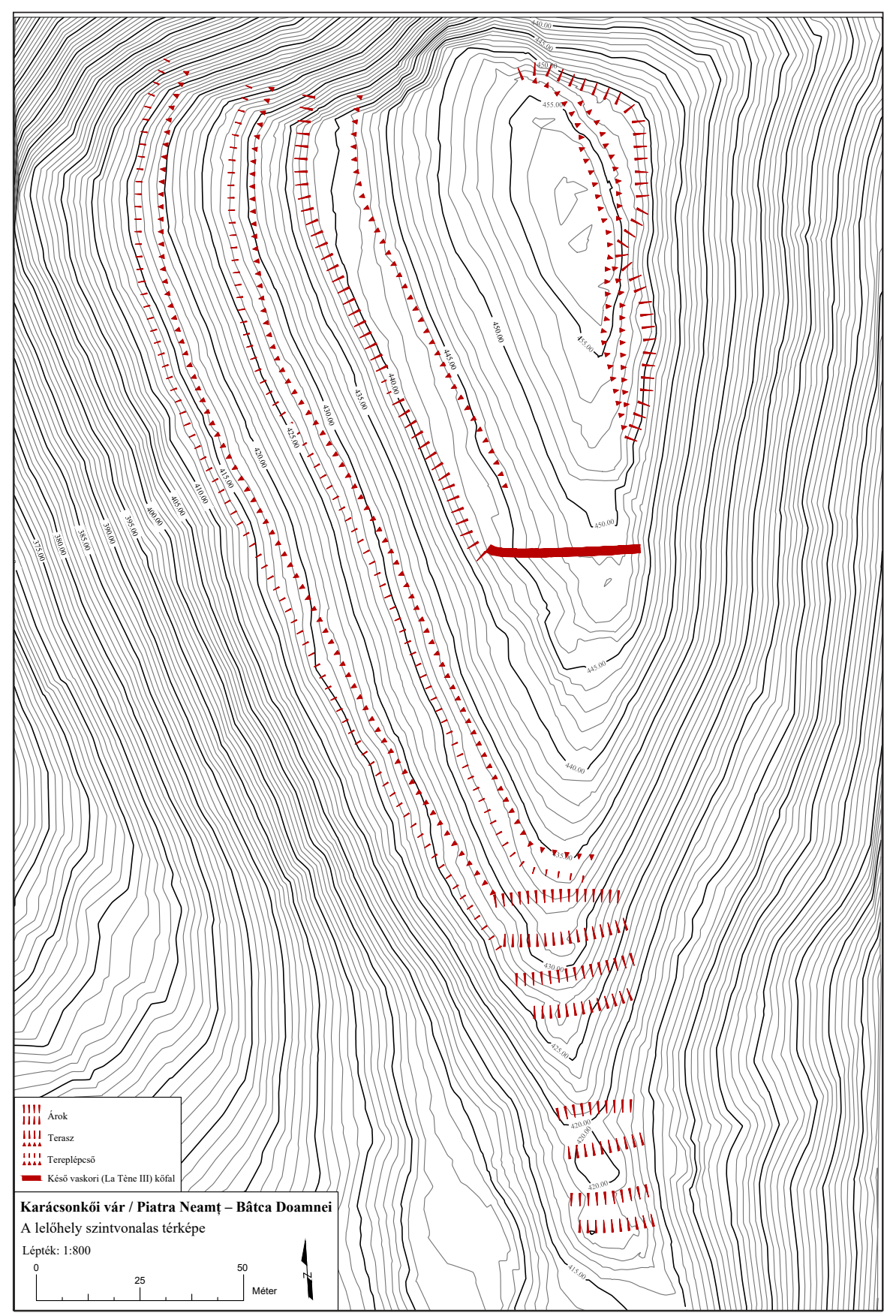

8. kép. A várhegy szintvonalas felmérése (a szerzö és a CloudScale Digital Kft. munkája) szottak, a másiknak pedig hiányzott a koponyája; 1965-ben a nyugati teraszon további 10 , valószínűleg szintén keresztény rítusú temetkezés nyomaira bukkantak, köztük egy nő és két gyerek csontvázára (BoteZATU \& ŞTEFĂNESCU, 1969, 13-18). Közelükben egy faszerkezetü építmény maradványait figyelték meg, van olyan kutató, aki ezt később templomépületként értelmezte (GosTAR, 1969, 12).

A vár erődítési jellegét és belső struktúráját illetően meglehetősen szerény feltárási megfigyelések és ismeretek alapján az Árpádkorban széleskörüen alkalmazott faszerkezettel (paliszádfallal) erődített, külső védelmi létesítményekkel (árkok, földtöltések) rendelkező vár képe bontakozik ki előttünk, melynek esetében az előnyös földrajzi adottságok nem tették szükségessé masszív földsáncok emelését a magaslat peremén. Az erősség középkori állapotáról értékelhető alaprajz nem készült korábban, a vaskori jelenségeket rögzítő (az őskori erődítmény kiterjedése $170 \times 110 \mathrm{~m}$, ld. Gostar, 1969, 7-16), méretarány nélküli felmérés georeferálása és terepi alkalmazása segítségével sikerült az egykori paliszád nyomvonalát megbízhatóan meghatározni ${ }^{3}$ (8. kép).

\section{TÁRGYI LELETEK: EDÉNYEK, ESZKÖZÖK, FEGYVEREK ÉS LÓSZERSZÁMOK}

Alapvető információt képvisel és a kutató számára széleskörü értelmezési lehetőségeket nyújt a vár területéről felszínre került középkori tárgyi hagyaték. A háztartási szemét gyanánt kidobált kerámia a közzétett darabok számát tekintve intenzívebb élettevékenységre utal, mint egy átlagos Árpád-kori ún. hegyi vár esetében. A főként fazekakból álló leletanyag-csoportot a felső harmadában kiszélesedő, illetve gömbös testü formák képviselik, rövid nyakkal, kihajló, egyszerüen profilált peremkiképzéssel. Díszítésükre a vonal, illetve hullámvonalak egyenközü és szabálytalan bekarcolása egyaránt jellemző, gyakori a körömbecsípés az edények vállán, az aljon pedig a fenékbélyeg (Scorpan, 1965, 444, Fig. 4) (9. kép). A hegyek másik oldalán, Kelet-Erdélyből a korabeli erődítmények területéről hasonló kerámiatípusok a Persányi-hegy-

\footnotetext{
A felmérés a CLOUDSCALE DIGITAL Kft. szakmai közreműködésével készült, itt mondok köszönetet Laczkó Nándornak.
} 
Sófalvi András • Karácsonkö vára: egy elöretolt helyőrség a Kárpátok keleti oldalán

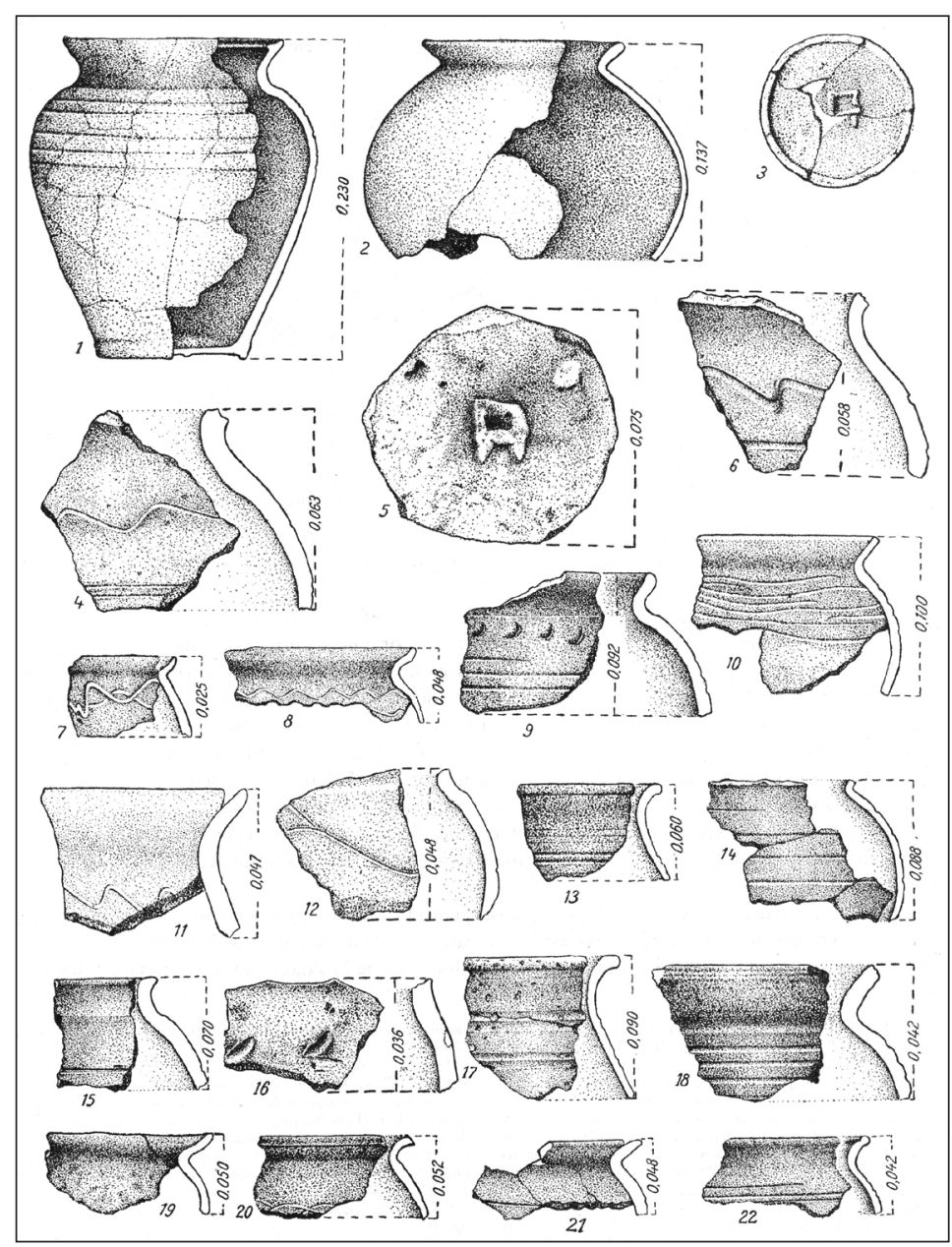

9. kép. Árpád-kori kerámialeletek a várból (SCORPAN 1965, 444, Fig. 4)

ség gerincén álló rikai toronyvárakból, valamint az Olt-parti szászugrai fa-földszerkezetü várból ismertek (SófaLVI, 2017, 202-203, 505-511. kép; Popa \& ŞTEFĂNeSCU, 1980, 496503). A Csíki-medence váraiból (Csíkrákos Pogányvár, Tusnád - Vártető) szintén kerültek elő hasonló jellegü kerámiatöredékek (ld. BotÁr, 2019, 369, 601).

A fémeszközök és -tárgyak elsősorban nem mennyiségük miatt, hanem sokszínüségük révén hívják fel magukra a figyelmet. A fegyverek közé egy teljes épségben megmaradt nyugati típusú kétélü kard, illetve további három kardpenge töredékei, keresztvasai és markolatgombjai, továbbá egyélü - feltehetően szablyához tartozó - pengedarab, kardhüvelykoptatók, több lándzsacsúcs, nyéltüskés és köpüs nyílcsúcsok, két keleti típusú öntött buzogányfej, valamint egy bárd tartozik (Mătasă \& Zamoșteanu, 1960, 347; SCORPan, 1965, 447, Fig. 5.1-5, 7-9; SPINEI, 1982, Fig. 7.1-14, Fig. 23.2; Agrigoroarei, 2008, 15). Kiemelendő a keltezés tekintetében is jó párhuzamokkal rendelkező ún. csónak alakú markolatgombbal felszerelt kard, melynek legközelebbi párhuzama a Csíki-medencéböl ismert (Kotormány), két másik hasonló példány pedig Háromszéken (Miklósvár, Kézdiszászfalu) került elő (BOTÁR, 2019, 557; BoRDI, 2008, 241-242, 2-3. tábla). Az erdélyi középkori kardok monografikus feldolgozásában Zeno-Karl Pinter a karácsonkői kard pontos megfelelőjét a Kis-Küküllő medréből előkerült kóródi kardban azonosította, utalva arra, hogy a moldvai lelet nagy valószínüséggel erdélyi eredetủ (PINTER, 2007, 88-89, P1. 39b). A lovaglás és a lóháton való hadviselés tartozékainak sorában hét darab tüskés sarkantyút (közülük három példány inkrusztációs díszítéssel), illetve egy csillagtarajos (?) sarkantyú töredékes darabját és kilenc kengyelt találunk, utóbbiak közt két fö típussal (lapos talpú, nyugati, illetve ívelt talpú, ún. keleti típusú kengyelek), ezeken belül többféle variánssal (MĂTASĂ \& ZAMOȘTEANU, 1960, 347; SCORPAN, 1965, 447-448, Fig. 5.11-15, Fig. 6; Spinei, 1982, Fig. 7.15-17, Fig. 8; Agrigoroarei, 2008, 14-15). A közölt vascsatok egy része lószerszám tartozéka (SCORPAN, 1965, 447, Fig. 5.10, 16; AgrigoroArei, 2008, 15), az előzetes közlemény patkókat és zablákat is említ (MĂTASĂ \& ZAMOșTEANU, 1960, 347) (10-11. kép). A közzétett fegyverleletek sokfélesége és a típusok széles skálája felveti azt a kérdést, hogy mindezek tartozhattak-e egyazon csapatnem felszereléséhez? A kengyeleken keresztül közelítve meg a problémát, jól ismert, hogy a kerek formájú kengyelek egyáltalán nem voltak jellemzők a honfoglaló magyarságra, még kevésbé a nyugati lovasságra, a karácsonkői leletek közül három viszont ebbe a csoportba tartozik. A típus fö jellemzője az ívelt talpaló és a vállába kovácsolt fül, illetve gyakori a dudoros kiképzés a talpaló és a szárak találkozásánál. A kengyeltípust a Kárpátoktól keletre a besenyőkkel szokás kapcsolatba hozni (SpineI, 1982, 139, Fig. 29.3-4, 6-7, Fig. 31.1-2, Fig. 34.1-2; PÁlóczi HorvÁth, 2014, 31, 13-14. kép), és Kárpát-medencei előfordulásuk általában szintén besenyő jelenlétet feltételez (HAVAssY, 1996, 18; PÁLÓcZI Horváth, 2014, 51, 30. kép). A kengyeltípus viszont a Magyar Királyság területére a 13. században betelepült kunoknál is továbbélt (Nagykamarás - Bánkút, Kunszentmárton - Jaksorérpart) (PÁLóczi HoRvÁTH, 2014, 129, 85. kép 1-2; KovÁcs, 1986, 278). A moldvai Coșna-i kincsleletben 13-14. századi tárgyakkal 
Sófalvi András • Karácsonkö vára: egy elöretolt helyőrség a Kárpátok keleti oldalán
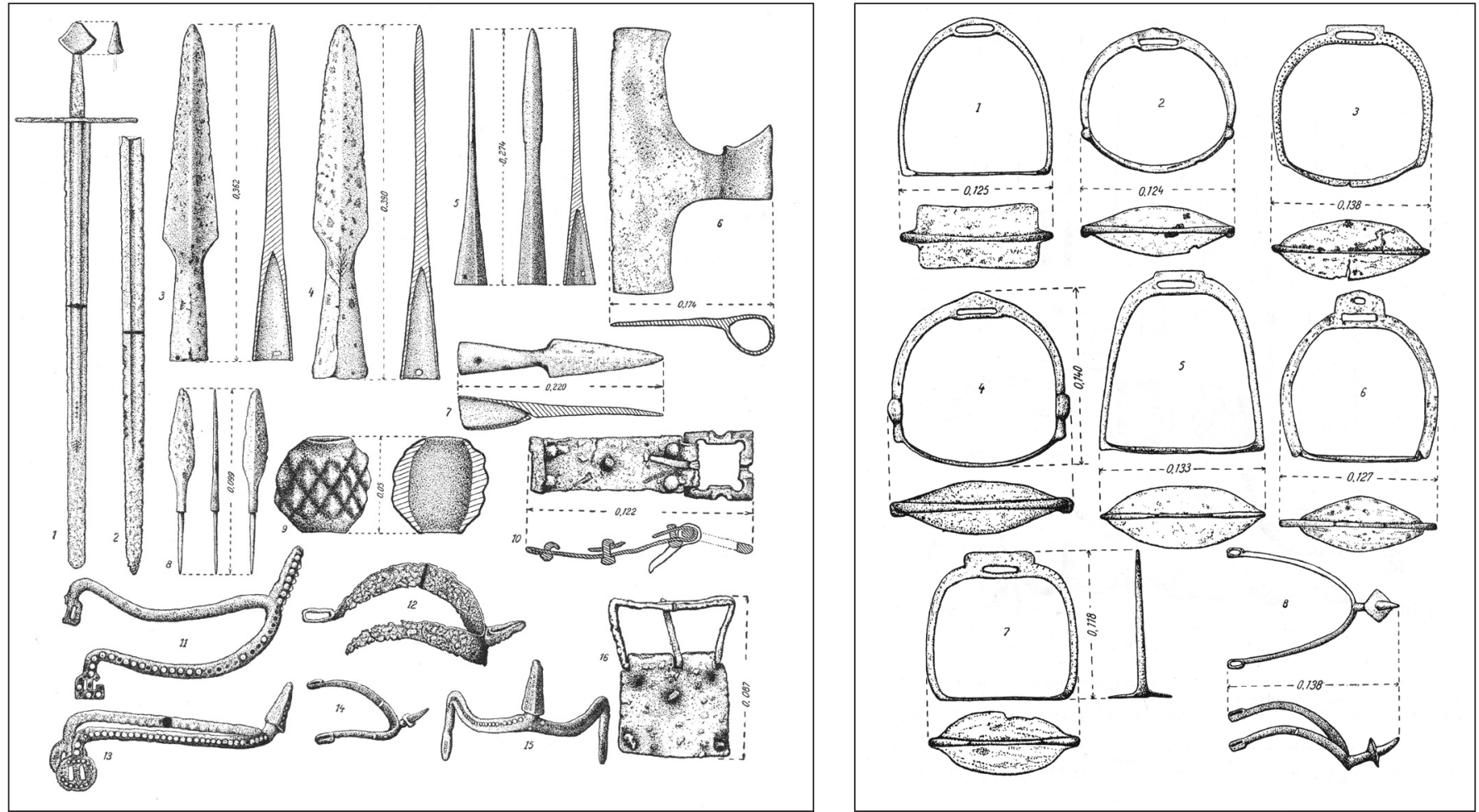

10-11. kép. Fegyverleletek és lószerszámok tartozékai (SCORPAN 1965, 447-448, Fig. 5-6)

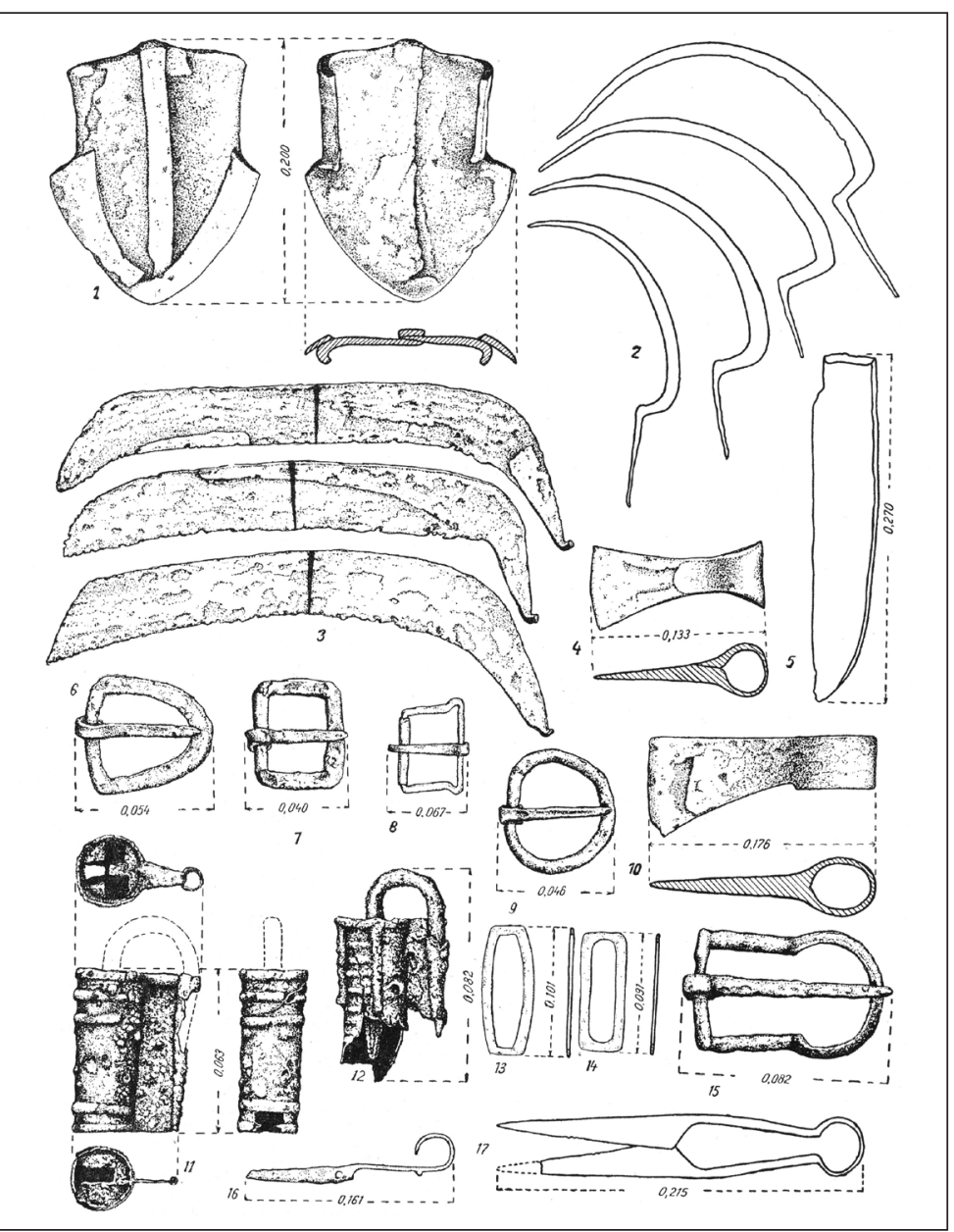

12. kép. Mezögazdasági eszközök, használati tárgyak (SCORPAN 1965, 450, Fig. 7) együtt előforduló „,besenyő típusú” kengyel (Spiner, 1982, Fig. 34.1-2) szintén azt jelzi, hogy a tárgytípus nem köthető kizárólagosan a besenyőkhöz. A karácsonkői fegyverek és a lovassági felszerelés alapján megfogalmazható, hogy a dudoros kengyek olyan könynyüfegyverzetü, adott esetben buzogányt is viselő lovas íjászok kellékei, akik nem használtak sarkantyút, és a lándzsával, karddal, tüskés sarkantyúval, egyenes talpalójú kengyellel felszerelt vitézek pedig egy átmeneti típusú lovasság jelenlétének tárgyi maradványai lehetnek.

A fémtárgyak sorában a legfeltünőbb a mezőgazdasági eszközök jelenléte a várban: egy ép ekevas, csoroszlya, több kasza és sarló tartozik a leletanyaghoz (MǍTASĂ \& ZamoșteAnu, 1960, 347; SCORPAN, 1965, 450, Fig. 7.1-5, 10; SpineI, 1982, Fig. 9; Agrigoroarei, 2008. 14). A mindennapi gazdálkodásban használt eszközök és kellékek tovább bővítik a fémtárgyak sorát: fejszék, üllő, horgok, csiholók, csipeszek, ollók, lakatok és övcsatok tartoznak ezek közé. (MĂTASĂ \& ZamoșteAnu, 1960, 347; SCORPAN, 1965, 450, Fig. 7.6-9, 11-17; Agrigoroarei 2008. 14) (12. kép). 
Sófalvi András • Karácsonkö vára: egy elöretolt helyörség a Kárpátok keleti oldalán

\section{KRONOLÓGIA}

Az áttekintett tárgyakat analógiáik alapján szükebb-tágabb időhatárok közé lehet keltezni, viszont bizonyos tárgytípusok (pl. a tüskés sarkantyúk és a kétélü kardok) alapvetően a 12. század második fele és a 13. század közepe közé helyezik a leletek datálásának súlypontját. A legfontosabb darabok egy ezüst brakteáta és egy ereklyetartó mellkereszt (Scorpan, 1965, 451-452, Fig. 8-9; Agrigoroarei, 2008. 13) (13-14. kép). E két meghatározó jelentőségü lelet ugyanakkor a legtöbb vitára adott okot a vár funkciójának eddigi értelmezésben. Az első publikációban a pénzérme IV. Béla vereteként jelent meg (MăTASĂ \& ZAMOȘTEANU, 1960, 347), de Scorpan középkori leleteket bemutató tanulmánya óta a román közlemények III. Béla korabeli pénzérmének tartják (Spinei, Agrigoroarei). A magyar kutatók egy része óvatos a verettípus uralkodóhoz kapcsolásában (GYÖNGYÖssy \& WinTER, 63, Taf. 17.370-378). A T alakú kereszt fölött kettős kereszttel, alul két rozettával vert éremkép egyértelmü bizánci hatást mutat, mely III. Béla (1172-1196) révén épült be a magyar királyi szimbólumok közé, viszont IV. Béla (1235-1270) nagyapját tartotta példaképének, úgy az uralkodás tekintetében, mint jelképes megnyilvánulásaiban. A legfrissebb Árpád-kori éremkatalógus IV. Béla uralkodásának elejére (1241 elé), még erdélyi hercegségének idejére keltezi a brakteátát, az újabb pénztörténeti kutatások tükrében (То́тн \& KISs, 2020, 17, 154, 22.7.1.1). A vár köré szőtt megalapozatlan törté-

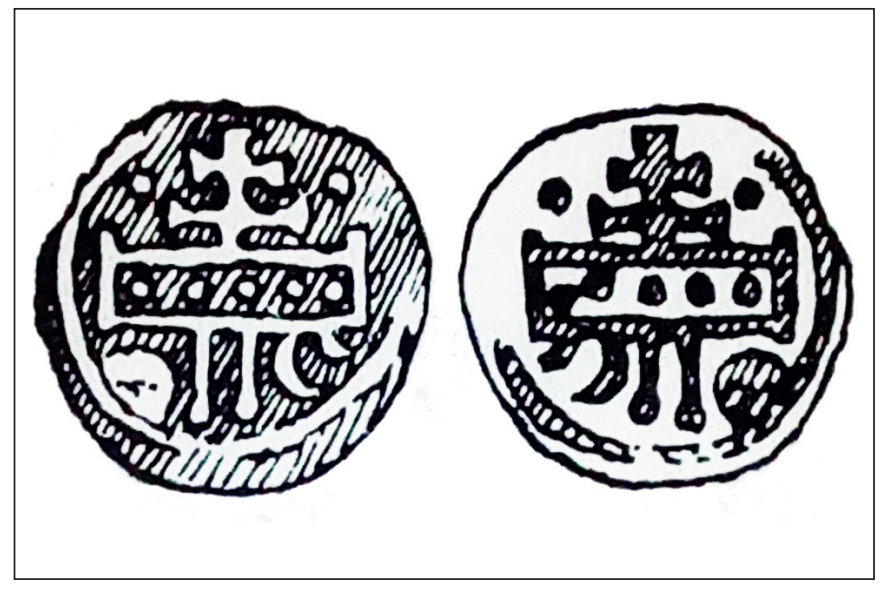

13. kép. IV. Béla korabeli brakteáta (SCORPAN 1965, 451, Fig. 8)

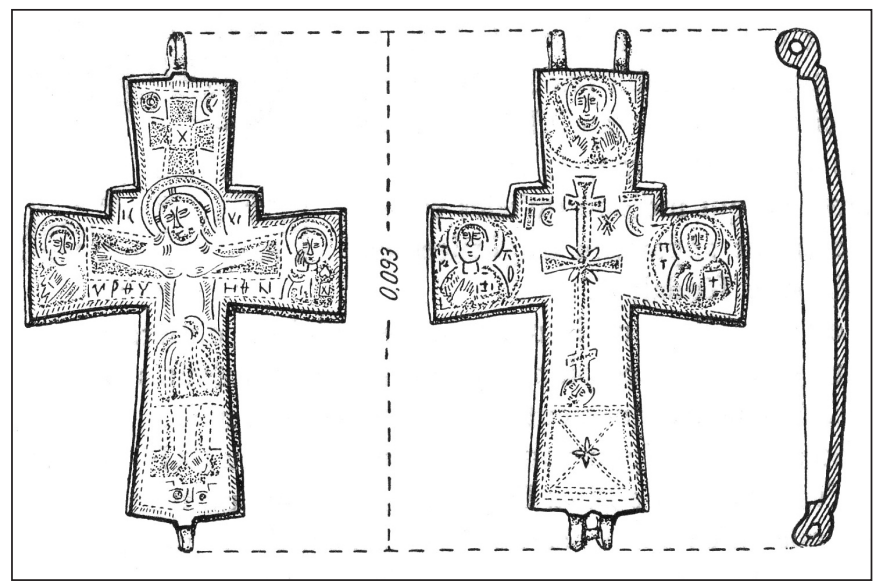

14. kép. Bizánci típusú mellkereszt (SCORPAN 1965, 452, Fig. 9)

nelmi teóriák alapját képezi az a bronzból öntött enkolpion, melynek gyökerei keletre mutatnak. A csuklós pántokkal egymáshoz rögzített elö- és hátlapból álló, belül üreges, latin kereszt formájú korpusz egyenesen lezárt végű szárai enyhén kiszélesednek. A kereszt felületét niellós technikával mintázott alakok díszítik. Elölapján a megfeszített Krisztus dicsfénnyel övezve, lába alatt talapzat, fölötte kisebb kereszt a nappal és a holddal; Krisztus kinyújtott karja mellett pedig Szüz Mária és Szent János alakjai, a kereszt oldalszárai fölött és alatt bekarcolt görög betűs névrövidítések. A korpusz hátlapjának közepén IC XC betüpárral közrefogott keresztábrázolás, mely egy Ádám fejen áll; a kereszt oldalszárainak végződésében Pál és Péter feliratos, a függőleges szár felső végződésében Szent Miklós mellképek medalionjai láthatók (ld. SPINEI, 1982, 108).

Az általában szentföldi típusúnak nevezett ereklyetartó mellkeresztek viszont nemcsak a Közel-Keleten és a Bizánci Birodalom területein terjedtek el, hanem a latin rítusú közösségeknél is elöfordultak (Itália, Cseh Királyság, Magyar Királyság) a 10-12. században (SzathmáRi, 1995, 225; LANGÓ, 2016, 64-65). Csehországi és magyarországi öntőminták egyértelmüen alátámasztják, hogy ilyen kereszteket nemcsak keleti (ortodox), hanem a nyugati keresztény területeken is készítettek. A karácsonkői leletanyag előzetes közleménye mindössze a fentiekben bemutatott keresztről tett említést, utólag viszont kiderült, hogy még két ún. kijevi típusú ereklyetartó mellkereszt is napvilágra került a várban (SPINEI, 1982, 88). Jelenlétük egy fontos útvonal meglétét jelzi közvetett módon a Kijevi Nagyfejedelemség és a Kárpát-medence között (kijevi típusú ereklyetartó mellkereszt a hegyek innenső oldalán Kotormányból ismert). (ld. BotÁr, 2019, 550, 528. kép) 
Sófalvi András • Karácsonkö vára: egy elöretolt helyőrség a Kárpátok keleti oldalán

A karácsonkői vár szerepének tudományos interpretációjában döntő jelentősége van a nyugati típusú tárgyak bizonyos csoportjainak (kétélü kardok, tüskés sarkantyúk), ugyanis ezek előfordulása a lelőhelyen nem magyarázható kereskedelmi kapcsolatokkal, hanem adott fegyvertípusokat és harcmodort használó, illetve alkalmazó katonai egység (a szakirodalomban félkönnyü/félnehéz, vagy átmeneti típusú lovasságnak egyaránt nevezett), azaz a kor tipikus magyarországi harcosainak jelenlétét tanúsítja a Kárpátoktól keletre. Ez az a tényező, amely az ideológiamentes módszertani elveket követő kutatók számára már az első pillanatban feltünt, ugyanis más moldvai lelőhelyeken szinte párhuzam nélküli. Szórványos 13-14. századi kardmarkolatgomb ismert a Suceava megyei Coșna-ról (m. Todoskány). (Spineı, 1982, Fig. 34-35). Figyelemreméltó, hogy ez a lelőhely a Borgói-hágón átkelö útvonal mellett található.

\section{KAPCSOLAT A HÁTORSZÁGGAL - UTAK}

Erdélyből a moldvai Karácsonkő felé vezető legrövidebb útvonal a Békás-patak szurdokvölgyén át modern korunk vívmánya. Az Aranyos-Beszterce-Kis-Beszterce mentén, illetve a Tölgyesi-szoroson Erdélybe érö út folytatásának napjainkban használt vonala Borszék, Maroshévíz, majd a Maros szorosán keresztül nagyrészt szintén modern kori, és a Maros-szurdokát a történelmi időkben nem használták. Tárgyunk szempontjából így különös jelentősége van a Sóvidékről a Görgényi-fennsíkon haladó ún. Só-útnak (13. századi használatát korabeli nyílcsúcs bizonyítja - ld. Sófalvi, 2017, 126, 53. kép 8), mely a Gyergyói-medencéböl a Pricske-tető mellett kelt át a Gyergyói-havasokon (közelében 14. századi pallost leltek - vö. DEMJÉN, 2016, 135, 1. ábra) a Tölgyesi-szoros irányába. Az útnak volt egy délkeleti leágazása Gyergyóbékás felé (a Balázs-, illetve a Zsédán-patak mentén, - ld. PusKÁs-KolozsváRI, 2020, 190), ahonnan már könnyen elérhető volt Karácsonkő. A történelmi földrajz eszközeivel még két, a középkorig visszavezethető út léte igazolható, melyeken keresztül az Erdélyi-medencéből Karácsonkőre lehetett átkelni: az ún. Beszterce útja Bélbor irányából, a Szászrégenből jövő út pedig a Görgény-patak völgyén keresztül jutott Tölgyes felé (Puskás-Kolozsvári, 2020, 190-193). A Gyergyói-medence késő Árpád-kori településtörténete az elmúlt bő évtized régészeti kutatásai során kezdett kibontakozni (1d. DemJÉN, 2016).

\section{A HATÁRVÁR ÉS A KORABELI VÁRSZERVEZET VISZONYA}

Az Árpád-kori Magyar Királyság legjelentősebb adminisztratív intézményének, a várispánságnak a müködését az elmúlt évtizedek kutatásai egyre világosabban feltárták, melynek keretében a határvédelem szervezete is jól körvonalazhatóvá vált (KRISTÓ, 1988; ZsolDOS, 2000). Erdély nyugati és központi részeivel szemben a vármegyék északi és keleti sávjai, a Nagy-Szamos-Sajó, a Maros és a Küküllők felső folyásának vidéke, valamint a Homoród mente közvetett régészeti és nyelvészeti adatok alapján ennek a határvédelmi szervezetnek a része volt. Feltünő ugyanis, hogy a jelzett régiókban, a középkori vármegyék területén a régészeti feltárások során számos olyan fa-földvár vált ismertté a 20. század második felében folyt kutatások eredményeképpen, melyek nem voltak vármegyei központok. Ide sorolható a Szamosok találkozásánál épült Kozárvár, a Sajó partján Sajósárvár, a Kelemen-havasok előterében pedig a felsőszászújfalusi/kusmai sáncvár. A Maros-mentén a Nyárád-torkolatával szemben épült malomfalvi sáncvár, illetve az írott forrásokban említett (1228), de részleteiben nem ismert Vécs vára is ide tartozik (Sófalvi, 2017, 74). Noha írott adatokkal nem bizonyítható ezeknek a kelet-erdélyi, 11-12. századi leletekkel rendelkező létesítményeknek a határvédelmi szerepe, viszont más régiók (a Magyar Királyság északi és nyugati peremterületei) oklevelekkel adatolt, hasonló jellegü építményei alapján joggal feltételezzük, hogy a nevezett erősségek ún. megyei háttér nélküli várispánságok, vagy határvárispánságok központjául szolgáló várak voltak (vö. Zsoldos, 2000, 115). A Küküllők felső folyásának vidékén, a későbbi Székelyföld központi részén körvonalazható udvarhelyi királyi magánuradalom területén a 12. század végétől feltehetően erdőispánságot hoztak létre, hasonlóképpen, mint a királyság északi peremterületein található erdőuradalmak esetében. Ennek területén ugyancsak épültek várak (Rika-erdei toronyvárak 12. századi leletekkel - ld. Sófalvi, 2013), melyeknek minden bizonnyal jelentős szerepük volt a határvidék felé vezető utak ellenörzésében is. 
Sófalvi András • Karácsonkö vára: egy elöretolt helyörség a Kárpátok keleti oldalán

A karácsonkői fa-földvár intézményes kapcsolata a hegyeken inneni vármegyék hálózatával a régióra vonatkozó írott források teljes hiánya miatt valószínűleg sosem lesz pontosan meghatározható, legfeljebb modellezhető: adott határvármegye területén müködő határvárispánság alá rendelt határvár (ilyenre a nyugati határ mentén Sopron vármegye szervezete kínál párhuzamot, ld. Zsoldos, 2000, 115).

\section{KARÁCSONKŐ SZEREPE A KORABELI KÜLPOLITIKÁBAN}

Az Aranyos-Beszterce folyó völgyének Moldva felé kinyíló völgytorkolatához épült karácsonköi vár azonban több volt egyszerű határvárnál, amit éppen sajátos pozíciója jelez számunkra. A határvidék külső permén épült vár nem pusztán katonai tényező volt, építtetői ennél összetettebb szerepet szántak neki. Az elöretolt helyőrség a moldvai részek, annak középső és északi területeinek felderítésére és népességmozgásainak megfigyelése céljából jött létre, földrajzi adottságainak tulajdoníthatóan viszont a vár kiváló menedékhely is volt.

A vizsgált időszakban az egyik legfontosabb politikai tényezőt a kunok jelentették a Kárpátok külső oldalán. A 12. században a Magyar Királyság és a kunok között csak közvetett kapcsolat volt ekkoriban, és nyílt katonai konfliktusra nem került sor (Kovács, 2014, 238). A 13. század elejétől, II. András (1205-1235) Halics ellen folytatott hadjáratai idején, ezekben a harcokban a kunok számos alkalommal szemben álltak a hódító magyar seregekkel (KovÁcs, 2014, 239-242). A magyar uralkodó hódításai eredményeképpen felvette Galícia (Halics) és Lodoméria királya címet, viszont a fejedelemség trónjára fiait ültette (a hadjáratokra és a halicsi eseményekre ld. MAKK, 2000, 175-177; KRISTó, 1998, 199-201, 221-222; Zsoldos, 2009, 27-29). E hódító hadjáratok útvonala az esetek többségében nem Erdélyen keresztül vezetett orosz földre, viszont a karácsonkői vár létesítését indokolt ebböl a szemszögböl is elemezni.

A kun kérdés az 1220-as évek közepétől egyházpolitikai síkra tevődött át, és a Magyar Királyság a pápaság támogatásával a kunok megtérítésébe kezdett. A magyar királyi udvarban a térítés egyik legfőbb támogatója Béla herceg volt, aki 1226-tól került Erdély élére, és ifjabb királyként kiadott erdélyi okleveleinek zöme kunországi terveivel kapcsolatos (KRISTó, 2003, 209-211; ZsoldOS, 2009, 30, 44-45). A Kárpátokon túli kun területeken folytatott keresztény hittérítés alig másfél évtized alatt komoly sikereket ért el a domonkos rendi szerzetesek tevékenységének köszönhetően, melynek intézményesítéséhez új egyházmegyét hoztak létre a korabeli országhatáron kívül (milkói püspökség - 1227). Az egyik kun fejedelem, Bortz és kíséretének hegyeken túli megkeresztelésében Róbert esztergomi érseken és három püspökön kívül Béla herceg is részt vett, mely az akciónak jelentős politikai súlyt adott (KovÁcs, 2014, 246-249). A hittérítés politikai következménye jól mérhető abban, hogy II. András 1233-ban felvette a rex Cumaniae címet is (KovÁCs, 2014, 253-255). A kun püspökség területe magyar érdekszférává vált, és minden bizonnyal elkezdődött a magyar királyság adminisztratív szervezetébe való integrálása, melynek ma még alig ismerjük az alapjait, viszont ez lehetett az a momentum, amikor Karácsonkő határvárispánsági székhely lett, és elkezdődött a jellegzetes várszervezet kialakítása. IX. Gergely pápa 1234 novemberében kelt oklevelében utalt a hegyeken túl áttelepedett magyar, német és más hívőkre (JAKÓ, 1997, 173).

\section{A VÉG: A TATÁRJÁRÁS}

A karácsonkői vár fennállásának a tatárjárás vetett véget. Ezt azonban a várban észlelt égésrétegek/ tüznyomok önmagukban még nem feltétlenül támasztják alá. A közzétett régészeti leletek felső időhatára az egyik legfontosabb bizonyíték e szempontból, ugyanis ezek nem lépik túl a 13. század közepét. A tárgyi maradványok sokfélesége, és az otthagyott fémanyag átlagon felüli gazdagsága szintén meghatározó e tekintetben. A fenti tényezők együttes mérlegelése alapján arra következtethetünk, hogy a karácsonkői vár tárgyi maradványai nem pusztán az ottani hétköznapok lenyomatát őrzik, hanem túlmutatnak azon. A leletek nemcsak a várban állomásozó kisebb katonai kontingens régészeti hagyatékát, hanem a tágabb környékről, a Moldva felé néző hegyek elöteréből, a mongolok mindent elsöprő hadereje elöl értékeivel ide menekült, többféle státuszú, etnikumú népesség anyagi kultúrájának maradványait képezik. A harcokban elesettek egy részét ide temették el, a támadásra utalnak a csontvázak egy részén megfigyelt rendel- 
Sófalvi András • Karácsonkö vára: egy elöretolt helyőrség a Kárpátok keleti oldalán

lenességek is. Erre az időszakra a templom körüli temetkezés gyakorlata szigorú egyházi elöírássá vált a Magyar Királyságban, és az ettől eltérő esetek mögött rendhagyó esemény (súlyos harc, járvány stb.) húzódik meg. Előfordul, hogy középkori várak területén temetkezések bukkannak napvilágra, Erdélyben pl. a nagygalambfalvi Várban vagy a nagyekemezői Burgbergen fedeztek fel kis számban sírokat (SóFALVI, 2017, 136, 987. jz.), ezek hátterében viszont ugyancsak nem mindennapi események állnak (hatalmaskodás, fegyveres összetüzés).

A túlélőknek, akik Karácsonkőről a hegyek útjain vagy kevéssé használt ösvényein el tudtak menekülni Erdély felé, aligha állt lehetőségükben visszatérni és ottmaradt értékeiket kimenteni. A tatárjárás nemcsak harci veszteségekkel, települések felprédálásával, templomok, kolostorok, lakóházak felgyújtásával és komoly emberáldozatokkal járt, hanem alapjaiban átalakította az Árpád-kori intézményrendszert, elindítva azt a folyamatot, mely a királyi vármegye és a várszervezet felbomlását eredményezte a következő évtizedekben. A hegyeken túli expanzió és a karácsonkői vár rendeltetése a tatárjárás után megszünt, és ezt követően többé már nem állomásozott magyar helyőrség benne.

\section{AJÁNLOTT IRODALOM}

Karczag, Á. \& Szabó, T. (2012). Erdély, Partium és a Bánság erőditett helyei. Várak, várkastélyok, városfalak, templomvárak, barlangvárak, sáncok, eröditmények a honfoglalástól a 19. század végéig. Budapest, Semmelweis Kiadó.

BiBLIOGRÁFIA

Agrigoroarei, V. (2008). Horodiştea de la Bâtca Doamnei [A Bâtca Doamnei-i erődítmény]. In Sălăgeanu, V. (ed.), 12 monumente din istoria românilor (pp. 11-18). Bucureşti - Cluj-Napoca.

Bordi, Zs. L. (2008). Középkori kardok a Székely Nemzeti Múzeum gyüjteményeiben. Acta Siculica - A Székely Nemzeti Múzeum Évkönyve. Sepsiszentgyörgy: Sámán Kiadó.

Botár, I. (2019). Havasok keblében rejtözö szép Csík. A Csíki-medence középkori településtörténete. Budapest: Martin Opitz Kiadó.

Botezatu, D. \& Ştefănescu, Gh. (1970). Contribuţii la studiul antropologic al populaţiei feudale timpurii din Moldova din sec. XIII e. n. [Adalékok a moldvai korai feudális lakosság 13. századi antropológiai kutatásához]. Studii şi Cercetări de Antropologie 7 (1), 13-18.

Demjén, A. (szerk.) (2016). Gyergyószentmiklós a régészeti kutatások tükrében. Kolozsvár Gyergyószentmiklós: Erdélyi Múzeum-Egyesület - Tarisznyás Márton Múzeum.

Gostar, N. (1969). Cetăţi dacice din Moldova [Moldvai dák várak]. București: Editura Meridiane.

Gyöngyössy, M. \& Winter, H. (2007). Münzen und Medaillen des Ungarischen Mittelalters 1000-1526. Alram, M. \& Winter, H. (hrsg.) Milano - Wien: Skira - Kunsthistorisches Museum.

Havassy, P. (szerk.) (1996). Zúduló sasok. Új honfoglalók - besenyők, kunok, jászok-a középkori Alföldön és a Mezőföldön. Gyulai katalógusok 2. Gyula: Erkel Ferenc Múzeum.

Jakó, Zs. (1997). Erdélyi Okmánytár. I. 1023-1300. Budapest: Akadémiai Kiadó. 
Sófalvi András • Karácsonkö vára: egy elöretolt helyőrség a Kárpátok keleti oldalán

Kovács, L. (1986). Viselet, fegyverek. In Kristó, Gy. Az Árpád-kor háborúi. Budapest: Akadémiai Kiadó.

Kovács, Sz. (2014). A kunok története a mongol hódításig. Magyar Östörténeti Könyvtár 29. Budapest: Balassi Kiadó.

Kristó, Gy. (1988). A vármegyék kialakulása Magyarországon. Budapest: Magvető Kiadó.

Kristó, Gy. (1998). Magyarország története 895-1301. Budapest: Osiris Kiadó.

Kristó, Gy. (2003). A korai Erdély (895-1324). Szeged: Szegedi Középkorász Műhely.

Langó, P. (2016). A négyszállási I. temető bronz keresztjei. In Bánkiné Molnár, E. (szerk.), Vizöntő. Ünnepi kötet a Jászságról Bathó Edit tiszteletére (pp. 67-75). Szolnok: Damjanich János Múzeum.

Makk, F. (2000). A tizenkettedik század története. Budapest: Pannonica Kiadó.

Mályusz, E. (1951). Zsigmondkori oklevéltár. I. 1387-1399. Budapest: Akadémiai Kiadó.

Mătasă, C. \& Zamoșteanu, I. (1960). Săpăturile de la Piatra Neamț [A Piatra Neamț-i ásatások]. Materiale şi Cercetări Arheologice 7, 339-349.

Mikecs, L. (1943). A Kárpátokon túli magyarság. In Deér, J. \& Gáldi, L. (szerk.), Magyarok és románok (pp. 441-507). A Magyar Történettudományi Intézet Évkönyve. Budapest: Athenaeum.

Pálóczi Horváth, A. (2014). Keleti népek a középkori Magyarországon. Besenyők, úzok, kunok és jászok müvelödéstörténeti emlékei. Budapest - Piliscsaba: Archeolingua.

Pinter, Z-K. (2007): Spada şi sabia medievală în Transilvania şi Banat (secolele IX-XIV)[A középkori kard és szablya Erdélyben és a Bánátban, 9-14. század]. Bibliotheca Brukenthal VII. Sibiu: Muzeul Național Brukenthal.

Popa, R. \& Ştefănescu, R. (1980). Şantierul arheologic Ungra. Jud. Braşov [A szászugrai régészeti feltárás, Brassó m.]. Materiale şi Cercetări Arheologice 14, 496-503.

Puskás-Kolozsvári, F. (2020). A Tászok-tető írott köveinek lehetséges párhuzamairól, különös tekintettel a moldvai területeken levőkre. In Fehér, B. \& Ferenczi, G. (szerk.), Ösi írásaink. Tanulmánykötet a Magyarságkutató Intézet által 2019. december 12-13-án rendezett konferencián elhangzott elöadásokból (pp. 183-199). Budapest: Magyarságkutató Intézet.

Scorpan, C. (1965). L’ensemble archéologique féodal de Bîtca Doamnei. Dacia N. S. 9, 441-454.

Sófalvi, A. (2013). Egy disszertáció margójára: a Rika-erdei várak és az udvarhelyi királyi magánuradalom kérdése. In Egyed, E., Pakó, L. \& Weisz, A. (szerk.), Certamen I. Előadások a Magyar Tudomány Napján az Erdélyi Múzeum-Egyesület I. szakosztályában (pp. 165-174, 525-530). Kolozsvár: Erdélyi MúzeumEgyesület.

Sófalvi, A. (2017). Hadakozás és önvédelem a középkori és fejedelemség kori Udvarhelyszéken. Kolozsvár: Erdélyi Múzeum-Egyesület. 
Sófalvi András • Karácsonkő vára: egy elöretolt helyőrség a Kárpátok keleti oldalán

Spinei, V. (1982). Moldova în secolele XI-XIV [Moldva a 11-14. században]. Bucureşti: Editura Ştiințifică şi Enciclopedică.

Szathmári, I. (1995). Bizánci típusú ereklyetartó mellkeresztek Békés és Csongrád megyében. Móra Ferenc Múzeum Évkönyve - Studia Archaeologica 1, 219-264.

Tóth, Cs. \& Kiss, J. G. (2020). Az Árpád-kori magyar pénzek katalógusa III. - II. Andrástól Ottóig. Catalogue of Árpádian Coinage III. From King Andrew II to King Otto. Opitz Numismatica 3. Budapest: Martin Opitz Kiadó.

Zsoldos, A. (2000). Confinium és marchia. (Az Árpád-kori határvédelem néhány intézményéről). Századok 134 (1), 99-116.

Zsoldos, A. (2009). Nagy uralkodók és kiskirályok a 13. században. Magyarország története 4. Budapest: Kossuth Kiadó. 